\title{
Andreas Albertsen \\ Brugerbetaling, ventelister og afgifter: personligt ansvar for egen sundhed?
}

Personligt ansvar er et centralt begreb i den politiske og den akademiske debat om sundhedspolitik. Tanken er, at hvis folk er ansvarlige for at leve en livsstil med en betydelig sundhedsrisiko, så har de også et ansvar for de konsekvenser, der kan følge heraf. Trods denne umiddelbare appel er der fremført stærke kritikker af personligt ansvar i en sundhedskontekst. Det fremføres, at sådanne tilgange overser den betydelige effekt, sociale og naturlige omstændigheder har på menneskers helbred, at det vil betyde en ubarmhjertig skæbne til dem, der træffer risikobetonede valg, eller basere sig på en indsamling af information, der langt overskrider privatsfærens grænser. Held-egalitarismen er et naturligt udgangspunkt for denne diskussion. Denne teori om fordelingsmæssig retfærdighed fokuserer på individers valg og ansvar. Dette muliggør en diskussion af, hvorvidt forskellige tiltag fremført i og omkring den held-egalitaristiske litteratur undgår nogle af de kritikker, der ofte rejses mod teorier, der søger at anvende idéen om personligt ansvar i en sundhedskontekst. Hvilken model der er mest attraktiv, er stærkt betinget af den kontekst, den søges indført i.

Nye teknologier, nye sygdomsmønstre og en aldrende befolkning aktualiserer diskussionen af, hvorledes vi bør prioritere samfundets og sundhedsvæsnets knappe ressourcer. Personligt ansvar er et centralt begreb i den politiske og akademiske debat herom. I diskussionen af konkrete sundhedstiltag og sundhedspolitikker inddrages det personlige ansvar ofte. Med henvisning til denne idé foreslås det at lægge afgift på cigaretter eller lade alkoholikere vente længere på en ny lever end dem, der har leversvigt af andre grunde (Veatch og Steinfels, 1974; Glannon, 2009). Personligt ansvar i sundhed er ikke et entydigt begreb, men diskuteres her som havende to elementer: 1) Når mennesker har muligheden for frit og informeret at vælge mellem forskellige livsstile, så er de ansvarlige for de sundhedsmæssige konsekvenser af dette valg, og 2) vi bør holde personer ansvarlige for de sundhedsmæssige konsekvenser, der opstår som følge af sådanne livsstilsvalg. I de seneste årtier har implikationerne af personligt ansvar $\mathrm{i}$ en sundhedskontekst været genstand for en omfattende akademisk debat (Buyx, 2008; Buyx og Prainsack, 2012; Dworkin, 1981; Leichter, 2003; Minkler 1999; Nielsen, 2013; Nielsen og Axelsen, 2012; Reiser, 1985; Veatch og Steinfels, 1974; Veatch, 1980; Wikler, 1987, 2002). I politiske debatter spiller idéen ind. Den britiske Labour-regerings store sundhedsudspil Choosing 
Health fokuserede på at give individer information til at træffe sunde valg (Department of Health, 2004). I Tyskland har flere tiltag indenfor sundhedsforsikringer tilstræbt at give incitamenter til at træffe sunde valg - også gennem mistede fordele for dem, der ikke gør (Schmidt, 2008). Idéen om personligt ansvar er indenfor den politiske filosofi nært forbundet med held-egalitarismen og denne teoridannelses syn på fairness. Held-egalitarismen er en valgsensitiv teori, der betoner, at fordelinger kun er retfærdige, og kun når de ikke afspejler omstændigheder men derimod menneskers valg (Cohen, 1989; Arneson, 1989; Lippert-Rasmussen, 1999). Af samme grund er det ikke overraskende, at vi finder både historiske og aktuelle forsøg på at give held-egalitaristiske bidrag til debatten om retfærdighed og sundhed (Albertsen og Knight, 2014; Le Grand, 1991; Roemer, 1993; Segall, 2010; Voigt, 2013). Denne artikel søger at bidrage til denne del af den held-egalitaristiske litteratur gennem en diskussion af forskellige sundhedstiltag fremkommet i og omkring den held-egalitaristiske litteratur.

Artiklen præsenterer kort den held-egalitaristiske idé om fairness og dernæst tre bekymringer vedrørende personligt ansvar i sundhed og held-egalitarisme i sundhed. Herefter diskuteres styrker og svagheder ved seks konkrete institutionelle tiltag, der i større eller mindre grad søger at holde folk ansvarlige for egne valg. Udgangspunktet for diskussionen er kritikker kendt både fra den medicinsk-etiske diskussion om personligt ansvar og fra den held-egalitaristiske litteratur. Kritikkerne går på, at tilgange, der betoner personligt ansvar i sundhed, risikerer at overse, at den betydelige effekt, sociale og naturlige omstændigheder har på menneskers helbred, vil betyde en ubarmhjertig skæbne til dem, der træffer risikobetonede valg, og vil basere sig på en indsamling af information, der langt overskrider privatsfæren. Held-egalitarismen synes at være et oplagt udgangspunkt for dem, der er tiltalt af personligt ansvar i sundhed men er bekymrede over disse kritikker. Det skyldes, at held-egalitarister er principielt imod at lade fordelinger afspejle uvalgte omstændigheder, og at der i den held-egalitaristiske litteratur er brugt meget energi på at komme med principielle forsvar imod de øvrige to indvendinger. Artiklen diskuterer med inspiration fra held-egalitarismen forskellige ansvarsinspirerende modeller, vi kunne indføre i en sundhedskontekst, og diskuterer, hvorvidt disse rammes af de respektive kritikker.

Diskussionen er selvsagt ikke uden antagelser og klare begrænsninger. Modellerne vurderes under antagelser, der tilstræber at tage diskussionen under ikke-ideelle forudsætninger. De væsentligste antagelser er, at vi meningsfyldt kan tale om, at nogle (men ikke alle) mennesker kan tilskrives ansvaret for deres egen, ringere sundhedstilstand, og at vi ikke umiddelbart ved, om en 
given person er ansvarlig eller ej. Artiklen benytter sig af de brede kategorier naturlige og sociale omstændigheder til at beskrive tilfælde, hvor folk ikke er ansvarlige, men baserer sig ikke på noget specifikt syn på, hvilke betingelser der skal være til stede, før man meningsfyldt kan sige, at en person ikke er ansvarlig for sit livsstilsvalg. Selvom det tilstræbes at gøre diskussionen anvendt $\mathrm{i}$ forhold til egentlige politiske tiltag, er debatten på flere punkter overordnet og idealiseret. Det diskuteres ikke, hvilket ansvar samfundet har for at sikre lige muligheder og eliminere de omstændigheder, der påvirker menneskers helbred, og de muligheder, de har for at passe på dette. Det betyder, at kun få ord er brugt på andre (uretfærdige) uligheder, som fx de uligheder i indkomst eller beskæftigelse, der påvirker menneskers helbred. Tilgangen er yderligere afgrænset i den forstand, at den diskuterer fordelingsmæssig retfærdighed indenfor sundhed. Det betyder at diskussionen ikke har inddraget andre værdier og hensyn såsom effektivitet, solidaritet eller gensidighed, der kunne siges at være vigtigere end retfærdighed i en sundhedskontekst. Det følgende afsnit præsenterer held-egalitarismen som generel teori om fordelingsmæssig retfærdighed, og hvorledes en bestemt udvikling heri er særlig relevant for diskussionen i en sundhedskontekst.

\section{Held-egalitarisme og sundhed}

Held-egalitarismen er en indflydelsesrig teori om fordelingsmæssig retfærdighed. Centralt i denne er bidrag fra G.A. Cohen (1989) og Richard Arneson (1989). Begge argumenterer for, at hvorledes folk stilles relativt til hinanden ikke bør afspejle omstændigheder men derimod menneskers valg. En nyere formulering af held-egalitarismen betragter fordelingen af samfundets goder og byrder som retfærdig, når, og kun når, menneskers relative position afspejler deres respektive udøvelse af ansvar (Lippert-Rasmussen, 1999). Dette kan siges at indeholde to distinkte elementer. Et der tilsiger, at menneskers relative position ikke bør afspejle omstændigheder, der er udtryk for held, og et der indebærer, at denne gerne må variere med folks egne valg. Held-egalitarister har forskellige syn på, hvorledes det bedst forstås, og hvilke betingelser der skal være opfyldt, før noget er en ikke-valgt eller valgt ulighed. John E. Roemer (1993) fokuserer på uligheder, hvor folks relative position ikke afspejler deres relative indsats for at undgå noget skadeligt eller opnå noget godt. Segall (2010) argumenterer for, at uligheder, der ikke afspejler valg, vi rimeligvis kan forvente, at folk undgår at træffe, er uretfærdige. Alex Voorhoeve (2005) argumenterer for, at vi skal bekymre os om værdien af de forskellige muligheder, folk står overfor. Knight (2013) mener, uretfærdigheden opstår, hvis folk ikke opnår den forventede værdi af de risici, de løber. 
Selvom disse teoretiske forskelle er interessante, vil de ikke blive behandlet indgående her. De udtrykker bestemte forståelser af, hvad det er, held-egalitarister mere specifikt bør mene udgør en retfærdig fordeling typisk gennem forskellige forståelser af, hvad der udgør en valgt ulighed. De argumenter, der præsenteres og diskuteres i det følgende, kan for så vidt anvendes, uagtet hvilket af ovenstående man foretrækker.

Efter den kortfattede præsentation af held-egalitarismen og nogle nyere udviklinger af denne vil et forskelligartet men vigtigt argument blive præsenteret. En pointe med stor relevans for artikelens tema er et argument fremført af Serena Olsaretti. Hun har introduceret den indflydelsesrige idé om, at en ansvarssensitiv teori som held-egalitarismen indeholder to forskelligartede elementer: Et kaldet ansvarets grundlag, der beskriver, hvilke faktorer vi mener folk er ansvarlige for, og et kaldet princippet om indsatser, der specificerer de konsekvenser, vi skal lade et sådant ansvar have for personen (Olsaretti, 2009: 170). Det betyder, at blot det at konstatere, at en person er ansvarlig for sin egen ringere position, ikke siger noget endeligt om, hvorledes vi rent institutionelt skal forholde os til det.

I en sundhedskontekst er denne udvikling af held-egalitarismen både interessant og opklarende. Det betyder, at det selv under antagelsen af, at nogle faktisk er ansvarlige for deres egen ringere sundhedstilstand, stadig er et åbent spørgsmål, hvilke institutionelle tiltag vi principielt bør indføre for at lade folks adfærd påvirke deres relative position. Herudfra udspringer artiklens idé om at diskutere styrker og svagheder ved sådanne modeller. Overordnet kan man lade tilstedeværelsen af ansvar få konsekvenser for tre forhold: kvaliteten af behandlingen (herunder adgangen til behandling), prisen på behandlingen og ventetiden til behandlingen (Dworkin, 1981). Disse kan udformes på forskellig vis og kombineres, men for overskuelighedens skyld angår diskussionen her de rene modeller, hvor der kun varieres på én faktor. Flere af disse modeller er fremført i og omkring den held-egalitaristiske litteratur, men der findes ingen samlet diskussion af deres respektive styrker og svagheder. Forslagene vurderes på, om de under de nævnte ikke ideelle antagelser undgår gængse kritikker af held-egalitarister, alt imens de fastholder de held-egalitaristiske ambitioner om en fordeling der afspejler menneskers valg. Inden denne diskussion kan tages, er det nødvendigt eksplicit at opridse kritikken af held-egalitarismen og personligt ansvar i en sundhedskontekst.

\section{Kritikken af personligt ansvar}

I den akademiske debat er der fremkommet flere forskelligartede kritikker af at introducere personligt ansvar i en sundhedskontekst. De tre mest markante vil 
blive fremhævet her, inden deres relation til og relevans for held-egalitarismen klarlægges. Den første går på, at idéen om personligt ansvar i en sundhedskontekst slet og ret overser noget helt fundamentalt. Hovedpointen er, at sådanne tilgange overser sociale omstendigheder, der påvirker menneskers helbred og menneskers livsvalg. Det understreges i denne kritik, at menneskers sygdomme i høj grad skyldes faktorer, der ikke har noget med deres valg at gøre. Mennesker bor i forurenede byer, lever i boliger af varierende kvalitet og slides af arbejdet, de udfører i løbet af dagen. Udover dette påvirkes de livsstilsvalg, vi som mennesker træffer, også af naturlige omstændigheder. Kritikerne fremfører, at tilstedeværelsen af disse ydre omstændigheder betyder, at en sundhedspolitik, der fokuserer på personligt ansvar, overser vigtige og væsentlige problemstillinger og i sidste ende risikerer at holde mennesker ansvarlige for en sygdom, der reelt ikke, eller kun i meget ringe grad, relaterer sig til valg, de har truffet (Daniels, 2011; Magnusson, 2010; Minkler, 1999; Resnik, 2007). Den anden kritik går på, at i situationer hvor folk er ansvarlige for deres ringere sundhedstilstand, vil det være ubarmhjertigt at holde dem personligt ansvarlige herfor (Wikler, 1987). Idéen er, at man dermed må nægte hjælp til mennesker, der har handlet ansvarspådragende, og som følge af deres egne frie og frivillige valg stilles meget ringere end andre. Hvis en person træffer et valg med en betydelig negativ konsekvens for eget helbred, så ligger han så at sige, som han har redt. Det har fået nogen til at argumentere for, at teorier, der betoner personligt ansvar, er ubarmhjertige overfor dem, der træffer sådanne valg. Dette vil blive omtalt som ubarmhjertighedsindvendingen.

Den tredje kritik angår karakteren af de oplysninger, der skal frembringes for at kunne sige noget om, hvorvidt en person er ansvarlig for sin (ringere) sundhedstilstand. Det vil typisk være i en situation, hvor vi ønsker at være sikre på, at det ikke er ydre omstændigheder, der er skyld i dette. Det er blevet fremført, at oplysninger kan have en sådan karakter, at selve indsamlingen af dem er grænseoverskridende, forkert og indgribende i dybt personlige forhold. (Harris, 1995). Det kan opfattes som nedværdigende og urimeligt for en patient $\mathrm{i}$ et kritisk sygdomsforløb at skulle redegøre for, hvorvidt den aktivitet, der førte til den ringere sundhedstilstand, var valgt eller snarere en vane, der kan spores tilbage til tidlig barndom, opdragelse eller andre uvalgte forhold. Kritikken vil herefter blive diskuteret under overskriften skamfulde afsløringer.

Artiklen diskuterer styrker og svagheder ved forskellige modeller for personligt ansvar fremkommet i og omkring den held-egalitaristiske litteratur. Det vil blive gjort ved at se på, i hvor høj grad de nævnte modeller formår at undgå disse væsentlige indvendinger. Det skal bemærkes, at disse indvendinger er forskelligartede. Den første kritik kan fremføres med udgangspunkt i en af 
held-egalitarismens iboende værdier, mens de øvrige udspringer i et andet syn på fordelingsmæssig retfærdighed. Det er centralt for held-egalitarister, at fordelinger ikke afspejler folks omstændigheder. Alligevel er det en ofte fremført kritik, at held-egalitarisme i en sundhedskontekst vil have lige netop denne konsekvens (Cavallero, 2011; Wikler, 1987, 2002). For de to øvrige kritikker gælder det, at de oftest opfattes og diskuteres som eksterne kritikker af heldegalitarismen. Flere har fremført og diskuteret varianter af ubarmhjertighedskritikken (Anderson, 1999; Feiring, 2008; Fleurbaey, 1995; Voigt, 2007) og kritikken om skamfulde afsløringer (Wikler, 1987; Wolff, 1998). Af samme grund har held-egalitarister på et principielt niveau gjort meget for at afvise disse (Albertsen, 2013; Arneson, 2000, 2004; Knight, 2009; Segall, 2010; Stemplowska, 2013; Tan, 2012). Uagtet styrken af disse teoretiske argumenter har held-egalitarister forsømt diskussionen af, om disse kritikker rammer forskellige modeller for at introducere personligt ansvar i en sundhedskontekst. Det er denne diskussion, der vil blive taget op her.

\section{Forskel i behandlingens kvalitet}

Ser vi helt overordnet på den type forslag, der går ud på, at folk, der har handlet ansvarspådragende og som følge heraf har ringere sundhedstilstand end andre, skal behandles ringere i sundhedssystemet end andre, findes der to varianter. En stærk der indebærer, at folk helt nægtes behandling, og en svagere der tilsiger, at de skal modtage behandling af en ringere kvalitet ( $\mathrm{fx}$ ved at der stilles færre ressourcer til rådighed). Selvom positionen ikke finder mange forsvarere i litteraturen, er den teoretisk interessant. Ihukommende at diskussionen her tages under de to antagelser, at nogle, men ikke alle, er ansvarlige for deres egen ringere sundhedstilstand, og at vi ikke umiddelbart har sikker viden om, hvilke personer det gælder for, synes denne tilgang umiddelbart at være problematisk af flere grunde. Indfører vi et system, der nægter at behandle dem, der er ansvarlige, indebærer det en betydelig risiko for, at denne meget voldsomme konsekvens også vil ramme nogle, der reelt ikke er ansvarlige for deres egen sundhedstilstand. Et system, der tilstræber at nægte behandling til dem, der selv er ansvarlige for deres egen ringere sundhedstilstand, kunne suppleres af en praksis, der undersøger og afklarer, hvorvidt en given person reelt er ansvarlig for sit eget ringere helbred. Problemet herved synes at være, at en sådan undersøgelse risikerer at inddrage faktorer og forhold, som det synes ydmygende at skulle oplyse til tredjepart. Det betyder, at tilgangen synes sårbar overfor indvendingen om skamfulde afsløringer. Selv hvis vi kunne forestille os at en indledende undersøgelse kunne give klarhed over, hvem der var ansvarlig for egen sundhedstilstand uden at involvere skamfulde afsløringer, er der yder- 
ligere komplikationer for tilgangen. Det må siges, at de, der korrekt vurderes som værende ansvarlig for egen sygdom, overlades til en meget hård skæbne. Tilgangen, hvor folk nægtes behandling, synes dermed også at være ubarmhjertig og må samlet set siges i meget ringe grad at være i stand til at undgå de gængse indvendinger mod at anvende personligt ansvar i en sundhedskontekst.

Man kunne forestille sig den her diskuterede tilgang varieret således, at modellen i stedet tilstræbte at give de pågældende en ringere behandling end dem med uforskyldt dårligt helbred. Udover at det givetvis kan være lidt svært at forestille sig, hvorledes denne ringere behandling konkret skal praktiseres, er denne ændring stadig problematisk i forhold til de kritikker, de konkrete modeller her diskuteres ud fra. Det fjerner eller mindsker givetvis styrken af ubarmhjertighedskritikken, mens de øvrige kritikker synes at bevare deres styrke. Afslutningsvis bør det bemærkes, at både tilgangen, hvor behandling nægtes til dem, der selv er ansvarlige for deres sundhedstilstand, og den, hvor de gives ringere behandling, synes at have en fælles svaghed. I hvert fald et fællestræk som held-egalitarister, der ønskede at foreslå sådanne tiltag, må forholde sig til. Det synes intuitivt mærkværdigt at nægte folk muligheden for at lade deres handlinger have konsekvenser på anden vis end ringere helbred. Eller sagt på en anden måde: Hvis en person træffer et risikofyldt valg, der resulterer $\mathrm{i}$, at vedkommende har ringere helbred end andre, så synes der ikke umiddelbart at være gode grunde til at forbyde vedkommende at betale sig fra at modtage samme behandling (og helbred) som andre, for til gengæld økonomisk set at værre ringere stillet som følge af de risikofyldte valg. Held-egalitarister der måtte være tiltalt af de løsninger, der her diskuteres, skulle altså fremkomme med et argument for, hvorfor personer, der er ansvarlige for deres ringere sundhedstilstand, absolut skal være ved dårligere helbred end andre frem for blot på en eller anden parameter at være dårligere stillet som følge af deres egne valg. Den oplagte måde er at tillade folk at veksle en ringere sundhedstilstand til en økonomisk ulempe gennem en form for brugerbetaling. Denne afsluttende pointe giver anledning til at drøfte den type tiltag, hvor folk bliver bedt om at dække de omkostninger, deres adfærd medfører.

\section{Forskel i behandlingens pris}

I det følgende diskuteres to forskellige tiltag, der på hver sin måde forsøger at få folk til at dække omkostningerne, der følger af deres risikofyldte adfærd i relation til sundhed. Det første forslag synes enkelt i sin natur. Det går ud på, at alle de, der gennem egne valg påfører sig en sygdom, skal dække de omkostninger, behandlingen af sygdommen indebærer. ${ }^{2}$ Umiddelbart kan det lyde simpelt. En person pådrager sig en sygdom gennem sine egne valg, og dette 
har så nogle omkostninger, som denne person selv skal dække. Inden vi for alvor kan tage fat i diskussionen af, hvorvidt denne løsning undgår de relevante kritikker, er det nødvendigt at gøre opmærksom på, at omkostninger faktisk er et mere upræcist begreb i denne sammenhæng end ovenstående indikerer. Da spørgsmålet om, hvad omkostninger præcist dækker over, kan have betydning for vores vurdering af denne model, er det nødvendigt at bemærke usikkerheden omkring dette. Vi bør derfor starte med at overveje, hvad der tæller som omkostninger i denne sammenhæng. En række omkostninger, såsom opvarmning og oplysning af operationsstuen, synes egentlig upåvirket af, om den pågældende person pådrager sig en sygdom eller ej. For omkostninger til hospitalets administrative personale, lægens uddannelse eller anlægsudgifter synes det svært konkret at vurdere, om patienten også skal pålægges at betale en andel af disse udgifter. Alt dette vedrører, hvad der tæller som omkostninger forbundet med behandling. Lad os for nemheds skyld antage, at det er muligt at fastsætte dette præcist. Det vil herefter være nødvendigt at afgøre, hvorvidt patienten skal betale de fulde omkostninger eller blot en andel heraf. Begrundelsen for at lade dem betale udgiften er givetvis, at de belaster sundhedsvæsnet som følge af deres valg. Det er rigtigt, men for de fleste er alternativet ikke, at de ikke ville belaste sundhedsvæsnet, men derimod at de ville belaste det senere og på anden vis. Dette kan illustreres ved at betragte en person, der er ansvarlig for at ryge og derfor under den her diskuterede model skal dække udgifterne, der følger, når vedkommende får behov for behandling. Men hvis personen ikke havde røget, er det usandsynligt, at udgifterne til behandling for senere fremkomne uvalgte sygdomme ville have været 0 . Som følge heraf kunne man argumentere for, at det, folk burde betale, er den andel af deres omkostninger, der udgør forskellen mellem deres faktiske forbrug og deres forventelige/kontrafaktiske forbrug, i fald de ikke havde haft den pågældende adfærd. Ser vi bort fra disse problemer med at bestemme omkostningerne og hvilke omkostninger, der kan tilskrives en persons ansvar, så er det muligt at lave en vurdering af, hvorvidt hel eller delvis brugerbetaling undgår de nævnte kritikker. Tilgangen synes på lige fod med de ovenfor drøftede tiltag, hvor der varieres på kvalitet, at kunne kritiseres for at risikere at overse sociale og naturlige omstændigheder og for at være afhængig af en ydmygende indsamling af informationer. En væsentlig social omstændighed, der synes særlig aktuel i denne kontekst, er, hvorvidt folks økonomiske formåen afspejler uvalgte omstændigheder. Er der store uretfærdige økonomiske uligheder, synes det selvsagt problematisk, at store dele af befolkningen udelukkes fra at modtage behandling, blot fordi de uforskyldt ikke har råd. Hvis det er tilfældet, er det ikke i tråd med held-egalitarismen at lade sådanne forskelle blive til forskelle i sundhed gennem brugerbetaling. I tillæg 
hertil møder vi igen et trade-off mellem, hvor sikre vi ønsker at være på, at vi ikke opkræver betaling fra dem, der ikke selv er skyld i deres sygdom, og faren for at undersøgelserne, der skal kortlægge dette, beror på skamfulde afsløringer og manglende respekt for folk. Dog synes anklagen om ubarmhjertighed noget mindre relevant i denne sammenhæng. Det skyldes, at alle vil kunne modtage behandling, men ikke alle vil kunne modtage gratis behandling. Det kan selvsagt fremføres, at det stadig er en ubarmhjertig konsekvens for personer, hvor det både gælder, at de selv er ansvarlige for deres ringere sundhedstilstand og for, at de ikke har råd til at betale for det. I forlængelse heraf er det oplagt at se på en variant, hvis fortalere selv mener bedre afspejler held-egalitarismens intuitioner og undgår mange af de her nævnte problemer, der er ved omkostningsløsningen, som den blev præsenteret herover.

\section{Capellan og Norheim: afgifter på usunde valg}

Under indtryk af, at idéen om at holde folk ansvarlige for de omkostninger, der opstår som følge af deres valg, på mange måder er problematisk, har Alexander Cappellen og Ole Norheim $(2005,2006)$ fremført en alternativ variant. Deres model indeholder to forskellige elementer, der søger at holde folk ansvarlige for deres adfærd. De mener, at vi bør holde folk omkostningsansvarlige i den forstand, det forrige afsnit diskuterede det for en gruppe af sygdomme. Det gælder for de sygdomme, der helt eller delvist skyldes folks valg, og som (I) ikke er livstruende, (II) ikke begrænser politisk deltagelse eller fundamentale kapabiliteter, og (III) hvor omkostningerne er små i forhold til personens indkomst (Cappelen og Norheim, 2006: 315). De specifikke krav er tydeligvis tilføjet for at undgå nogle af de kontraintuitive konsekvenser, der blev diskuteret i det forrige afsnit. Dette er selvsagt en ret ad hoc måde at løse problemerne på, og teorien savner for så vidt at begrunde, hvorfor disse krav er udvalgt frem for andre. Den mest plausible begrundelse for lige netop disse krav synes at være, at de forsøger (i praksis) at undgå nogle af de problemer en ren traditionel heldegalitarisme har i forhold til at være ubarmhjertig og ramme folk, der ikke selv er skyld i deres sygdom. Det må siges, at denne måde at holde folk omkostningsansvarlige på synes at undgå ubarmhjertighedsindvendingen. Tilgangen synes dog i praksis at risikere at holde folk ansvarlige for sociale og naturlige omstændigheder, og selve afklaringen heraf kan fremstå ydmygende. Cappelen og Norheim mener dog, at det personlige ansvar også bør spille en anden rolle i tilfælde, hvor et eller flere af de tre kriterier ikke er opfyldt. I sådanne tilfælde mener de alligevel, at der er mulighed for at holde folk ansvarlige, blot på en anden måde. Det gøres ved at skifte fokus fra at holde folk ansvarlige for konsekvenserne af deres valg til at holde folk ansvarlige for selve valgene. I praksis vil 
dette ofte indebære, at folks valg pålægges en skat eller en afgift. De på denne måde indbetalte penge dækker så de udgifter, der opstår i forbindelse med, at nogle personers valg har den konsekvens, at de får en behandlingskrævende sygdom. De anfører som begrundelse for denne tilgang, at ansvar for omkostninger i disse tilfælde ville betyde, at de pågældende personer ville opleve en eller flere af følgende: livstruende konsekvenser, begrænsede muligheder for politisk deltagelse, og at omkostningerne har en uproportionel størrelse set i forhold til personens indkomst.

Som supplement hertil anføres det, at når folk træffer ensartede valg og dermed løber ensartede risici, så er eventuelle forskelle, der opstår imellem dem, udtryk for held (Cappelen og Norheim, 2005: 479). Denne sidste begrundelse er ikke klasssisk held-egalitaristisk, idet den indebærer en omfordeling mellem folk, der løber den samme risiko men opnår forskellige udfald. Denne tankegang er tættere på den variant af held-egalitarismen, der i litteraturen omtales som all luck egalitarianism (Segall, 2010). Det første, der skal siges om dette forslag, er derfor, at det på et væsentligt punkt afviger fra det heldegalitaristiske ideal, idet denne form for finansiering indebærer, at de, der løb en risiko men ikke blev syge, dækker dele af de udgifter, der er for folk, der løb tilsvarende risiko og blev syge. Det bør alligevel overvejes, hvorledes denne supplerende tilgang om ansvar for valg rammes af de øvrige kritikker. Først skal det bemærkes, at tilgangen ikke synes at lede til ubarmhjertige konsekvenser, idet folk faktisk behandles. På tilsvarende vis nødvendiggør tilgangen ikke ydmygende undersøgelser og kortlægninger af folks private forhold. Der synes ikke noget behov for at registrere folks trufne valg, de skal blot betale den pålagte afgift. Det kan dog som en praktisk omstændighed nævnes, at der findes aktiviteter, det er sværere at afgiftspålægge end andre. Hvorimod afgifter på faldskærme til fritidsbrug, alkohol og alpinski synes lette at implementere, er det sværere at afgiftspålægge det usunde valg at blive hjemme på sofaen. En måde at tilstræbe en løsning til dette problem på ville være at understøtte sundere aktiviteter økonomisk, fx at subsidiere adgangen til svømmehaller og fitnesscentre.

Det næste, der skal bemærkes, er, at tilgangen faktisk lader sociale og naturlige omstændigheder have en betydelig indflydelse. Det skyldes, at alle valg pålægges en afgift uden at tage i betragtning, om nogle grupper har sværere ved at undlade at træffe bestemte valg end andre. Problemet er således, at tilgange også tillægger folks valg moralsk betydning i tilfælde, hvor det ikke for alle, der træffer sådanne valg, synes rimeligt at tilskrive dem ansvar for de trufne valg. Så selvom der i idéen om, at alle der har en given risikoadfærd, synes at være en tiltalende tankegang, risikerer selv denne tilgang at tillade folks omstændig- 
heder at påvirke folks relative position. Effekten af dette må dog siges at være mindre end den, der kan forventes af den model, der holdt folk omkostningsansvarlige. Hertil skal lægges den allerede nævnte problematik, at dette andet element i teoridannelsen bevæger denne væk fra et klassisk held-egalitaristisk udgangspunkt og tættere på det, der i litteraturen omtales som all luck egalitarianism. Fra et held-egalitaristisk synspunkt er det klart problematisk, at denne tilgang både synes at holde folk ansvarlige for (nogle) uvalgte omstændigheder og sikrer omfordeling, der kompenserer for valgte forhold ved at omfordele mellem dem, der løber en ensartet risiko.

\section{Forskel i ventetid}

Ventelister er intet ukendt fænomen i sundhedsvæsnet. I den almindelige sundhedspolitiske debat betragtes de som ofte som et (nødvendigt) onde, der udtrykker ubalancer i sundhedssystemet. Ventelister kan udtrykke, at efterspørgslen efter behandling overstiger systemets kapacitet, og at folk af den grund må vente. Men det behøver ikke at være tilfældet. Ventelister mere generelt kan bruges som en prioriteringsmekanisme, hvilket i en dansk kontekst illustreres af SRSF-regeringens arbejde med en differentieret behandlingsgaranti, hvor kun nogle sygdomme har en behandlingsgaranti på én måned, mens andre sygdomme først garanteres behandling efter to. Det betyder i praksis, at patienter med bestemte sygdomme prioriteres højere end andre. Argumentet herfor er dog ikke baseret på ansvar, men på at disse sygdomme skulle have større behandlingsbehov end de, der skal vente to måneder. Ventelisterne, og måske snarere hvem der venter, kan således være udtryk for eksplicitte prioriteringer (Dworkin, 1981; Jensen, 2007). Spørgsmålet er så, hvorledes denne tankegang kan anvendes i forbindelse med personligt ansvar. Umiddelbart synes to praktiske indretninger nærliggende i relation til personligt ansvar. En hvor den enkeltes sygdomsforløb og årsager kortlægges, og en hvor bestemte sygdomme eller sygdomsårsager som udgangspunkt giver lavere prioritet, fordi de antages at være udtryk for, at personen ikke i tilstrækkelig grad har bestræbt sig på at undgå at blive syg. Valget mellem de to praktiske udformninger synes samtidig at være et trade-off mellem at risikere at lade folks omstændigheder influere deres position relativt til andre og en grundig potentiel ydmygende undersøgelse af deres personlige forhold. I den første udformning risikerer vi at skulle gennemføre sådanne undersøgelser, i den anden er risikoen at folk har sygdomme klassificeret som værende udtryk for personligt ansvar, af grunde de ikke kan gøre for. Et trade-off vi genkender fra de hidtil diskuterede modeller. Løsningen synes i de fleste tilfælde ikke at være ubarmhjertigt hård. Ingen nægtes behandling, men nogle kommer til at vente mere på den end andre - 
det kan dog være nødvendigt at lave ad hoc undtagelser for tilfælde, hvor øget ventetid i høj grad øger chancen for permanent forværret helbred. I det kommende afsnit vil vi se på en løsning, der potentielt også indebærer en venteliste, men som også giver folk muligheden for ikke at skulle vente.

\section{Feirings ventemodel}

Eli Feiring (2008) har præsenteret en variant af idéen om ventelister, hvis eksplicitte formål er at undgå flere af de indvendinger, der her drøftes. Selvom Feiring ikke er held-egalitarist, er det værd at overveje, om hendes tilgang til ansvar i sundhed er attraktiv i denne kontekst. Feirings idé udvikles i forbindelse med livsstilssygdommen fedme men kan fint anvendes i en bredere kontekst. Hun oplister en række grunde til, at det kan være praktisk svært og/eller normativt problematisk at arbejde med et ansvarsbegreb, der er bagudrettet i den forstand, at det beskæftiger sig med, hvorvidt folk selv er ansvarlige for deres sygdom, og så forsøger at holde folk ansvarlige herudfra. Det er netop et sådant ansvarsbegreb, der har været motivationen for de hidtil diskuterede tilgange, og den måde, Feiring problematiserer det på, relaterer sig netop til sociale og naturlige omstændigheder, skamfulde afsløringer og ubarmhjertighed. Feiring $ø$ nsker af disse grunde at tale om det, hun kalder et fremadrettet ansvar. Idéen er, at de, der kommer til sundhedsvæsnet med en behandlingskrævende sygdom, der kan relateres til deres livsstil, stilles overfor et valg. De kan indgå en aftale med sundhedsvæsnet, der indebærer, at de skal ændre deres livsstil fremadrettet. I fald de indgår en sådan aftale, vil de blive behandlet på lige fod med alle andre. Hvis de vælger ikke at indgå aftalen, vil de blive placeret længere tilbage på ventelisten. Det er dermed nærliggende at behandle Feirings forslag som en mildere variant af ventelisten behandlet ovenfor. Konceptet er grundlæggende, at folk ikke vurderes på deres fortidige ageren, men på det valg de træffer vedrørende deres fremtidige ageren. Hvis de ønsker at vedblive med at leve det liv, der har resulteret i denne sygdom, så får de en lavere prioritet i sundhedsvæsnet, end hvis de siger ja til at lægge deres liv om. Først diskuteres en række uklarheder i Feirings teori, herefter diskuteres det, hvordan Feirings position klarer sig i forhold til de relevante indvendinger. Der synes at være et behov for, at Feiring specificerer, hvilke konsekvenser det bør have, i fald nogen bryder en indgået aftale. Hun synes at være tiltalt af, at dette kan resultere $\mathrm{i}$ en nedprioritering i forhold til fremtidige behandlingsbehov. En anden komplikation, ${ }^{3}$ der synes relevant at nævne, er den, der opstår, hvis en person pådrager sig en sygdom, der skyldes personens egne valg, efter at denne person har aflagt sig denne adfærd, fx ved at holde op med at ryge. Hvis modellen ikke stiller krav til denne person eller blot stiller krav om at fortsætte med at 
være ikke-ryger, så forekommer den at ignorere personens eget ansvar i en grad, der synes problematisk. Hvis vi antager en rimelig afklaring på begge disse komplikationer, lad os da se på, hvorvidt Feirings teoridannelse kan undgå de gængse kritikker, og hvorvidt det er et alternativ, held-egalitarister kan omfavne. Feirings tilgang synes ikke at indebære risiko for at blive ubarmhjertig, idet en ansvarsjusteret venteliste næppe kan karakteriseres som havende en sådan karakter. Ej heller synes modellen i første omgang at få brug for undersøgelser, der kan involvere skamfulde afsløringer. Disse kan givetvis være nødvendige i forbindelse med at placere et ansvar for aftalebrud. På tilsvarende vis synes der at være et problem med sociale eller naturlige omstændigheder. I forhold til sådanne uvalgte omstændigheder er de hovedsageligt relevante $\mathrm{i}$ forhold til at influere folks evne til at overholde en indgået aftale. Feiring synes at tillade konsekvenser ved aftalebrud, uanset om det er sådanne omstændigheder, der ligger bag et aftalebrud. Det sidste, der skal bemærkes, er, at Feirings model i tilfælde, hvor folk har aflagt sig deres risikobetonede adfærd, ikke synes i stand til at lade denne adfærd få nogle konsekvenser - selv i situationer hvor adfærden er klart selvvalgt og tilgængelig uden nogen form for skamfulde afsløringer. Dette er klart problematisk i et held-egalitaristisk perspektiv, og det synes derfor tvivlsomt, at held-egalitarister direkte kan tage Feirings forslag til sig.

\section{Perspektiverende konklusion}

På baggrund af ovenstående kunne det være nærliggende at drage en konklusion om, at at det på baggrund af diskussionen er svært at vælge imellem de forskellige modeller for at holde folk ansvarlige. De har alle på forskellig vis svært ved at undgå at blive ramt af en eller flere af de væsentlige kritikker, der er blevet drøftet her. Men blot det, at det ikke er klart, hvilken model vi bør foretrække generelt, udelukker ikke, at der er værdifulde pointer i at tage diskussionen.

Selve det at diskutere forskellige modeller for personligt ansvar er vigtigt for den held-egalitaristiske litteratur. Det skyldes, at idéen om at nægte behandling til tider behandles som den held-egalitaristiske standardposition. Den ovenstående diskussion viser en pluralitet af mulige tiltag, held-egalitarister kan tilslutte sig. En pluralitet kritikker af held-egalitarismen i en sundhedskontekst burde notere sig. Idéen om at nægte behandling er ydermere problematisk som paradigmatisk eksempel på held-egalitarisme i sundhed, fordi vi faktisk har held-egalitaristiske grunde til at være skeptiske overfor denne løsnings ensidige fokus på, at de, der løber en risiko med deres helbred, skal have dårligere helbred end andre frem for blot at være dårligere stillet på et andet parameter. I tillæg hertil synes den også både ubarmhjertig og med risiko for at skulle 
anvende skamfulde afsløringer. For både ventelister og omkostninger gælder det, at der synes at være et trade-off mellem, hvor præcist vi ønsker at kortlægge ansvar for at undgå at holde folk ansvarlige for deres omstændigheder og faren for, at de afsløringer, vi beder folk om at lave, er skamfulde og ydmygende for dem. Det betyder at det kan have stor betydning for, om en løsning er attraktiv, hvor let og tilgængelig information sådanne vurderinger baserer sig på. Herudover kan det siges, at skulle vi overordnet set vælge mellem ventelister og brugerbetaling, synes det væsentligt, om samfundet som helhed er præget af uvalgte uligheder i indkomst og formue. Er dette tilfældet, kan vi have heldegalitaristiske grunde til at foretrække en model baseret på ventelister frem for brugerbetaling. Denne pointe om indkomst udtrykker en anden mere generel pointe. Selvom vi kan diskutere retfærdighed i sundhed, så vil vores vurdering af retfærdige fordelinger og retfærdige tiltag på sundhedsområdet spille sammen med vurderinger af, hvor retfærdigt andre goder og byrder er fordelt.

Modeller, der delvist nedtoner et fokus på ansvar, blev også drøftet. Det blev bemærket, at Capellan og Norheims alternative version af brugerbetalingsmodellen på et afgørende punkt afviger fra det held-egalitaristiske ideal og er nærmere all luck egalitarianism. For Feirings version af ventelisterne gælder det, at den afviger fra det held-egalitaristiske ideal, men også at den indeholder uklarheder, der gør, at den ikke oplagt er at foretrække som alternativ. Hverken Capellan og Norheims idé om at pålægge alle risikofyldte valg en afgift eller Feirings forslag til ventelister synes at undgå risikoen for, at vi ender med at holde folk ansvarlige for sundhedstilstande, der i høj grad skyldes bestemte omstændigheder. Held-egalitarister må ydermere være bekymret for, om ikke modellerne siger for lidt om statens ansvar for at eliminere sådanne omstændigheder. Det synes at være vigtigt for held-egalitarismen, men samtidig noget der glider i baggrunden i sådanne modeller, hvor alle valg pålægges en afgift, eller hvis alle, der ikke overholder aftaler med sundhedsvæsnet, stilles ringere af den grund. De mere rene modeller for brugerbetaling, venteliste eller behandlingens kvalitet synes mere oplagt at kunne kombineres med sådanne tiltag.

\section{Noter}

1. Temaet i denne artikel var centralt i kandidatseminaret "Ulighed i sundhed: Svære valg for individer og samfund", som jeg underviste i efteråret 2012. Jeg skylder derfor en tak til de studerende, der gennem drøftelser og diskussioner har bidraget til ovenstående. Herudover er jeg taknemmelig for konstruktiv kritik fra Martin Marchman Andersen, David V. Axelsen, Kristian Jensen, Søren Flinch Midtgaard, 
Lasse Nielsen, Thomas Søbirk Petersen, Jens Dambaard Thaysen og to anonyme reviewere.

2. Denne diskussion har haft stor gavn af Andersen (2014).

3. En komplikation påpeget af en reviewer.

\section{Litteratur}

Albertsen, Andreas (2013). Lader held-egalitarismen Fanden tage de uansvarlige sidste? Politica 45 (2): 217-232.

Albertsen, Andreas og Carl Knight (2013). A framework for luck egalitarianism in health and healthcare. Journal of Medical Ethics 6: 158-173.

Andersen, Martin Marchman. (2014). What does society owe me if i am responsible for being worse off? Journal of Applied Philosophy. DOI: 10.1111/japp.12054.

Anderson, Elizabeth S. (1999). What is the point of equality? Ethics 109 (2): 287-337.

Arneson, Richard J. (1989). Equality and equal opportunity for welfare. Philosophical Studies 56 (1): 77-93.

Arneson, Richard J. (2000). Luck egalitarianism and prioritarianism. Ethics 110: 339349.

Arneson, Richard J. (2004). Luck egalitarianism interpretated and defended. Philosophical Topics 32 (1/2): 1-20.

Buyx, Alena (2008). Personal responsibility for health as a rationing criterion: Why we don't like it and why maybe we should. Journal of Medical Ethics 34 (12): 871-874.

Buyx, Alena og Barbara Prainsack (2012). Lifestyle-related diseases and individual responsibility through the prism of solidarity. Clinical Ethics 7 (2): 79-85.

Cappelen, Alexander W. og Ole F. Norheim (2005). Responsibility in health care: a liberal egalitarian approach. Journal of Medical Ethics 31: 476-480.

Cappelen, Alexander W. og Ole F. Norheim (2006). Responsibility, fairness and rationing in health care. Health Policy 76 (3): 312-319.

Cavallero, Eric (2011). Health, luck and moral fallacies of the second best. The Journal of Ethics 15 (4): 387-403.

Cohen, G. A. (1989). On the currency of egalitarian justice. Ethics 99 (4): 906-944.

Daniels, Norman (2011). Individual and social responsibility for health, pp. 98-114 i Carl Knight og Zofia Stemplowska (red.), Responsibility and Distributive Justice. Oxford: Oxford University Press.

Department of Health (2004). Choosing Health: Making Healthy Choices Easier. Department of Health.

Dworkin, Gerald (1981). Taking risks, assessing responsibility. The Hastings Center Report 11 (5): 26-31.

Feiring, Eli (2008). Lifestyle, responsibility and justice. Journal of Medical Ethics 34 (1): 33-36. 
Fleurbaey, Marc (1995). Equal opportunity or equal social outcome? Economics and Philosophy 11 (01): 25-55.

Glannon, Walter (2009). Responsibility and priority in liver transplantation. Cambridge Quarterly of Healthcare Ethics 18 (1): 23-35.

Harris, John (1995). Could we hold people responsible for their own adverse health? Journal of Contemporary Health Law and Policy 12 (1): 147-53.

Jensen, Karsten Klint (2007). Skal rygere, overvægtige og ældre sættes bagerst i sygehuskøen?, i Kasper Lippert-Rasmussen og Jesper Ryberg (red.), Født og forbliver lige og frie?: om diskrimination og etik. København: Museum Tusculanums Forlag.

Knight, Carl (2009). Luck Egalitarianism. Edinburgh: Edinburgh University Press.

Knight, Carl (2013). Egalitarian justice and expected value. Ethical Theory and Moral Practice 16: 1061-1073.

Le Grand, Julian (1991). Equity and Choice: an Essay in Economics and Applied Philosophy. New York: HarperCollins Academic.

Leichter, Howard M. (2003). "Evil habits" and "personal choices": assigning responsibility for health in the 20th century. The Milbank Quarterly 81 (4): 603-626.

Lippert-Rasmussen, Kasper (2001). Egalitarianism, option luck, and responsibility. Ethics 111 (3): 548-579.

Magnusson, Roger (2010). Obesity prevention and personal responsibility: the case of front-of-pack food labelling in Australia. BMC Public Health 10 (1): 662.

Minkler, M. (1999). Personal responsibility for health? A review of the arguments and the evidence at century's end. Health Education og Behavior 26 (1): 121-141.

Nielsen, Lasse (2013). Taking health needs seriously: against a luck egalitarian approach to justice in health. Medicine, Health Care and Philosophy 16 (3): 407-416.

Nielsen, Lasse og David V. Axelsen (2012). Three strikes out: objections to Shlomi Segall's luck egalitarian justice in health. Ethical Perspectives 19 (II): 307-316.

Olsaretti, Serena (2009). Responsibility and the consequences of choice. Proceedings of the Aristotelian Society 109: 165-188.

Rakowski, Eric (1993). Equal Justice. Oxford: Clarendon.

Reiser, S. J. (1985). Responsibility for personal health: a historical perspective. The Journal of Medicine and Philosophy 10 (1): 7-17.

Resnik, D. B. (2007). Responsibility for health: personal, social, and environmental. Journal of Medical Ethics 33 (8): 444-445.

Roemer, John (1993). A pragmatic theory of responsibility for the egalitarian planner. Philosophy and Public Affairs 22 (2): 146-166.

Schmidt, H. (2008). Bonuses as incentives and rewards for health responsibility: a good thing? Journal of Medicine and Philosophy 33 (3): 198-220.

Segall, Shlomi (2010). Health, Luck, and Justice. Princeton: Princeton University Press. 
Stemplowska, Zofia (2013). Rescuing luck egalitarianism. Journal of Social Philosophy 44 (4): 402-419.

Tan, Kok-Chor (2012). Justice, Institutions, and Luck: the Site, Ground, and Scope of Equality. Oxford: Oxford University Press.

Veatch, Robert. M. (1980). Voluntary risks to health: the ethical issues. JAMA: The Journal of the American Medical Association 243 (1): 50-55.

Veatch, Robert M. og Peter Steinfels (1974). If national health insurance is enacted who should pay for smokers' medical care? The Hastings Center Report 4 (5): 8-10.

Voigt, Kristin (2007). The harshness objection: Is luck egalitarianism too harsh on the victims of option luck? Ethical Theory and Moral Practice 10 (4): 389-407.

Voigt, Kristin (2013). Appeals to individual responsibility for health. Cambridge Quarterly of Healthcare Ethics 22 (02): 146-158.

Voorhoeve, Alex (2005). Equal Opportunity, Equality and Responsibility. Ph.d.-afhandling, University of London.

Wikler, Daniel (1987). Who should be blamed for being sick? Health Education Quarterly 14 (1): 11-25.

Wikler, Daniel (2002). Personal and social responsibility for health. Ethics and International Affairs 16 (2): 47-55.

Wolff, Jonathan (1998). Fairness, respect, and the egalitarian ethos. Philosophy \& Public Affairs 27 (2): 97-122. 